\section{Survey of the Research Needs of the Potential Organic Ornamental Bedding Plant Industry in Maine}

\author{
Stephanie E. Burnett ${ }^{1,3}$ and Lois Berg Stack ${ }^{2}$
}

ADDITIONAL INDEX WORDs. floriculture, greenhouse

SUMMARY. Organic and conventional greenhouse growers in Maine were surveyed to determine the research needs of growers who may produce organic ornamental bedding plants. Organic growers were also asked to identify their greatest motivator to determine whether they feel that there is a greater market for organically grown ornamental plants. The greatest percentage $(75 \%)$ of organic growers indicated that they choose to grow plants organically because "it's the right thing to do." The second greatest percentage $(36 \%)$ of organic growers choose organic production techniques for ornamental plants because they grow food crops organically and consider it convenient to use only one production technique. A relatively small number of organic growers $(7 \%)$ considered the market for organic ornamental plants to be a strong motivator for growing organically. Organic growers were asked to select production issues that pose the greatest challenge for them from a list of common production problems. They considered insect and disease management and organic fertility, substrate, and $\mathrm{pH}$ management to be their greatest problems. Conventional growers primarily avoid organic production techniques because they consider organic fertilization or organic insect management to be too big of a challenge. Because organic and conventional growers consider insect and fertility or substrate management to be challenges facing organic growers, these topics should be top priorities for future research on organic greenhouse production.

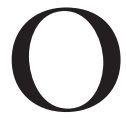
rganic agriculture is a rapidly growing sector in agriculture; sales of organic produce increased by $20 \%$ or more every year from 1990 through 2002 (Dimitri and Greene, 2002; Nelson et al., 2004). Vegetable and fruit sales represent the greatest percentage of overall organic production, followed by organic dairy products [U.S. Department of Agriculture (USDA), 2006]. Consumers choose organic food partly because it is assumed to be healthier due to lower pesticide residuals (Jolly, 1991). However, consumers who purchase organic food also consider organic production methods to have a less negative impact on the environment than

We gratefully acknowledge the Maine Agriculture Center for funding this research project.

Maine Agriculture and Forestry Experiment Station Publication \#3056.

We thank Scott Eidelman for helpful comments and suggestions on our survey, the University of Maine Psychology Department for use of their survey software, and Renae Moran and Donglin Zhang for their helpful comments on an early draft of this manuscript.

${ }^{1}$ Department of Plant, Soil, and Environmental Sciences, University of Maine, 5722 Deering Hall, Orono, ME, 04469

${ }^{2}$ University of Maine Cooperative Extension Service, 495 College Avenue, Orono, ME, 04473

${ }^{3}$ Corresponding author. E-mail: sburnett@maine.edu. conventional production techniques (Durham, 2007).

Research on the production and marketing of organic products has focused primarily on organic food. However, because consumers consider organic production to be environmentally safer than conventional production, they may be interested in purchasing nonedible crops such as bedding plants and cut flowers. This may represent a new market niche for growers and an opportunity to attract younger consumers who are typically more interested in organic food than are older consumers (Thompson, 1998 ).

For this reason, the production of organic ornamentals in the United States has been increasing. In 2005, organic nursery and greenhouse production covered 3331 acres (1348.0 ha) in the United States. It is unknown how much of this acreage was dedicated to ornamental plant production, but conventional greenhouse and nursery production consists largely of ornamental plants. While this is a relatively small production area, acreage of organic nurseries and greenhouses has increased $83 \%$ since 2004 (USDA, 2006). Thirty-three percent of growers responding to a survey from the Organic Farming Research Foundation grow herbs, floriculture, ornamental, or greenhouse products, mushrooms, or honey (Walz, 2004). Thus far, organic herbs and flowers have been sold primarily through the internet, community-supported agriculture groups (CSAs), and local farmers markets (Dimitri and Greene, 2002; Walz, 2004). Supermarket sales of organic ornamental plants have been thus far been limited.

Maine has 288 certified organic farms, the 10th highest number of organic farms in the United States (USDA, 2006). This indicates that Maine has a thriving organic market. Nearly all of these farms are food producers, but it is likely that consumers in Maine and throughout the United States would be interested in organic bedding plants as well because organic production is perceived to be better for the environment. And, on a national level, some large ornamental greenhouse growers are beginning to integrate organic production into their facilities in anticipation of increased consumer interest in organically grown ornamental plants or flowers.

Despite indications that consumer interest in organically grown ornamental plants is increasing, most, if not all, research projects involving organic growing methods focus on food crops. Organic ornamental bedding plants may be a new niche for bedding plant growers, but little to no research has addressed production issues involved in organic ornamental plant production. Therefore, the objective of this project was to survey growers to determine the perceived research needs of this emerging industry. Responses to the survey will be used to develop research projects that will support this new, potential area of production.

\section{Materials and methods}

A survey was developed to determine what research problems organic ornamental bedding plant growers face and what barriers prevent conventional bedding plant growers from converting to organic production. This survey contained 13 questions on the front and back of a legalsized sheet of paper. Four questions specifically addressed organic growers and one question was addressed only 
toward conventional growers. In addition to asking questions about the potential problems involved in organic ornamental bedding plant production, we included two basic respondent demographic questions. We also asked growers two questions to identify topics that would interest them at a fall workshop conducted after all of the surveys were returned. Participation in the workshop was free as a reward for participation in the survey. The survey was approved by the Institutional Review Board for the Protection of Human Subjects at the University of Maine.

We developed our mailing list from two sources: the list of businesses licensed as nurseries by the Maine Department of Agriculture, Food, and Rural Resources (MDAFRR) and the list of greenhouses that are certified organic by the Maine's local certification board, the Maine Organic Farmers and Gardeners Association (MOFGA). MDAFRR nursery licenses are required for all Maine businesses that sell plants, making us confident that we started with a comprehensive master list of Maine greenhouse growers. Business-type identifiers in the MDAFRR database allowed us to reduce the list to include only businesses that own greenhouses. We further reduced the list by removing all businesses known to be sales-only operations; these are primarily seasonal hoop houses at box stores and grocery chains. Some of the MOFGAlisted organic greenhouses are included in the MDAFRR list because they sell plants and are therefore licensed as nurseries. However, the MOFGA list allowed us to add 44 nonlicensed organic greenhouses to our database. These are businesses that grow plants in greenhouses for their own field production purposes rather than for direct sales.

We mailed our survey to the entire population of 636 conventional and organic greenhouse growers in Maine on 31 July 2007. On 27 Aug. 2007 , we mailed a second copy of the survey to those growers who had not responded to the first mailing. Both mailings included cover letters and self-addressed stamped return envelopes. All surveys were coded to track responses so that we could avoid mailing a second copy to respondents. Data were analyzed using frequency and means analysis in SAS (version 9.1; SAS Institute, Cary, NC).

\section{Results and discussion}

From a total mailing to 636 businesses, we received 269 complete and usable surveys. Thirteen additional surveys were returned as undeliverable. This yielded a $43.2 \%$ response rate. Twenty-six respondents are certified organic through Maine's local certification board, MOFGA $(10 \%)$, and 18 additional growers practice organic growing techniques but are not certified (Table 1). We combined responses from all growers who practice organic techniques for a total of 44 organic growers [ $17 \%$ of all growers (Table 1)]. The number of organic respondents is lower than might be expected based on the total number of organic growers reported by the U.S. Department of Agriculture (2006). However, we mailed the survey only to those certified organic growers who have greenhouses to eliminate responses from organic field crop growers and organic dairy farmers. The responding organic growers do not exclusively grow ornamental bedding plants; they typically produce a combination of vegetables and ornamental bedding plants in containers that are sold to retail consumers on-site or are planted in the field for production of vegetables, herbs, or cut flowers (data not shown).

Although Maine has the 10th highest number of organic growers among all states in the United States, conventional bedding plant growers greatly outnumber organic ornamental bedding plant growers. One hundred fifty-nine conventional growers $(60 \%$ of all respondents) returned the survey (Table 1). Many of the market channels used by conventional growers are similar to those used by organic growers. However, fewer conventional growers produce potted plants for use in on-site field production, although this is a significant portion of plant production for organic growers. Respondents who do not grow any ornamental bedding plants returned 61 of the remaining surveys (23\%) (Table 1).

SURVEY OF ORGANIC GROWERS. Organic growers were asked what motivates them to grow ornamental bedding plants organically to determine whether they perceive a thriving organic ornamental market. They selected the single greatest motivation from the following list:

I feel that growing organically is the right thing to do.

I grow food crops organically, so I decided to grow my ornamental crops the same way.

I see a market demand for organic ornamental bedding plants.

Other (they were asked to specify "other" responses).

The greatest number of respondents (27 growers, $61 \%$ of all organic growers) feel that organic production "is the right thing to do." Eleven growers $(25 \%)$ grow ornamentals

Table 1. Number and proportion of growers in Maine self-identified as using organic or conventional production techniques. $^{\mathrm{z}}$

Question Frequency $(\text { no })^{\mathrm{y}}$ Frequency (\%)

Do you grow ornamental bedding plants? Control the answer below that best reflects your business:

Yes, I'm certified organic. I grow at least some of my bedding plants organically.

Yes, I grow them organically, but, I'm not certified.

$26 \quad 10$

Total organic growers

Yes, I grow them only with conventional (that is, not organic) production methods

18

44

7

No, I don't grow ornamental bedding plants

159

17

No response

61

60

3

23

${ }^{z}$ Organic growers were certified organic or practiced organic techniques, but were not certified. The number and frequency of growers who responded to the survey, but who do not grow ornamental bedding plants, is also shown. A small number of growers returned the survey, but did not respond to this question (no response).

y The number of growers who were certified organic, organic but not certified, etc. 
organically because they grow edible crops organically, and none of the growers feel that a market demand is the greatest motivation for organic ornamental production (Fig. 1). Six growers (14\%) selected more than one response. All of those growers are ethically motivated to grow organically, five of six also find the convenience of growing all crops (edible and ornamental) organically to be a strong motivation, and three of six feel that there is a market for organically grown ornamentals. On a national level, a majority of organic growers are motivated by similar factors. They cite environmental concerns and concern about exposure of workers or family members to chemicals as the top motivations for choosing organic production (Walz, 2004). Growers consider the higher price premium typically obtained for organic products to be less motivating (Walz, 2004). This may be due to reports that while organic produce receives a premium price in retail markets, increased production costs and lower yields in organic systems result in comparable, but typically not higher, net return (Brumfield et al., 2000).

To determine what production issues organic growers perceive as problematic, they were asked the following question: "What are your most difficult challenges in growing organic ornamental bedding plants?

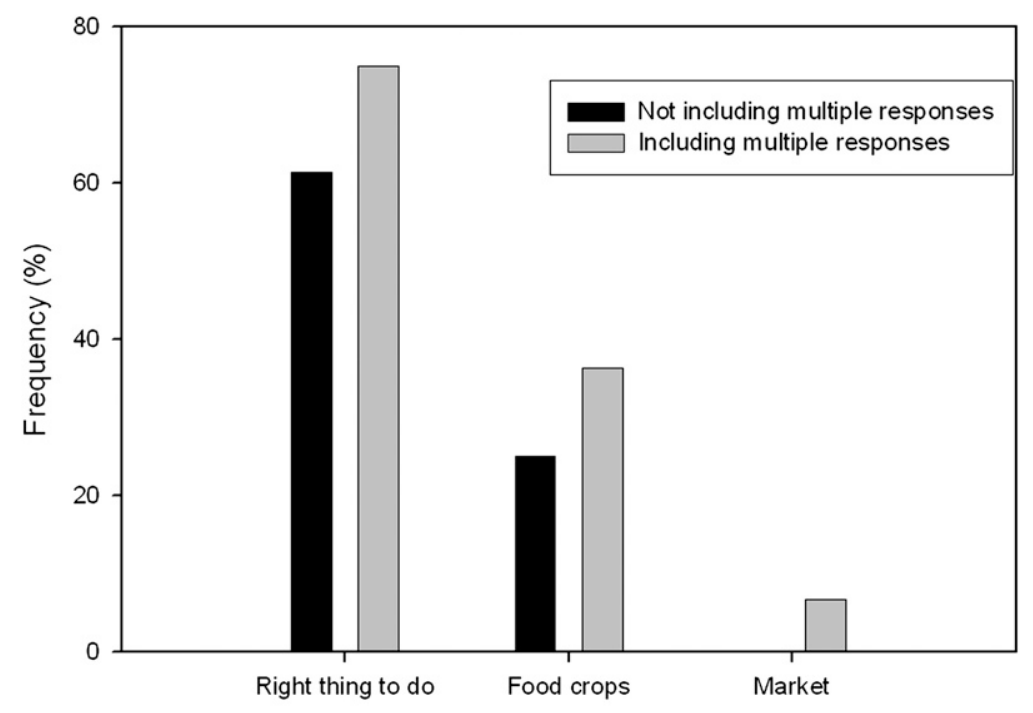

Responses

Fig. 1. Frequency of motivations for Maine growers to choose organic growing over other alternative production strategies. Respondents were asked to choose the greatest motivation factor; however, $14 \%$ of growers chose two options. For those responses, each selection was counted; thus, the total frequency is greater than $100 \%$. their greatest challenge in growing organic ornamentals (Fig. 2). It is not surprising that managing fertility, the potting mix, or substrate $\mathrm{pH}$ is a significant production challenge. Many organic container growers provide fertility by adding compost to growing media. Compost alone does not provide adequate fertility for container-grown plants (Bugbee and Frink, 1989; Chaney et al., 1980; Falahi-Ardakani et al., 1987). Growers often supplement compost-provided fertility with liquid organic fertilizers such as fish emulsion. Compost and liquid organic fertilizers tend to mineralize slowly in substrates. Many bedding plants are sold about 8 weeks after seedlings are transplanted; nutrients are often needed more rapidly than they are released via mineralization. This is further complicated because mineralization rates are slower when substrate temperatures are cool (Kraus et al., 2000). Low temperatures are common in spring greenhouse production because growers are reluctant to heat more than necessary in their effort to manage fuel costs. Fertility is further reduced because substrate recipes recommend adding peat, perlite, vermiculite, or bark to straight compost to improve drainage (Kuepper and Everett, 2004). These substrate components add negligible fertility. Available nutrients are easily lost when containers are irrigated due to the low anion-holding capacity of container substrates (Bilderback, 2002). Other organic fertilizers such as fish emulsion or soybean meal may supplement nutrients provided in compost. Viola fertilized with organic liquid fertilizer had greater shoot dry weights than plants fertilized with conventional fertilizer (Kelley and Biernbaum, 2000). Overapplication of liquid fertilizer as the sole fertility source is costly and may leach nitrogen and phosphorus. Furthermore, although many growers use liquid organic fertilizers, appropriate application rates in compost-based substrates have not been determined.

No other challenges on the list were concerns for greater than $50 \%$ of growers, but at least a portion of growers expressed concern about the consistency and/or availability of organic supplies $(25 \%)$, managing elongation of plants (18\%), water quality and quantity (14\%), and seed germination (11\%). Eleven percent of 


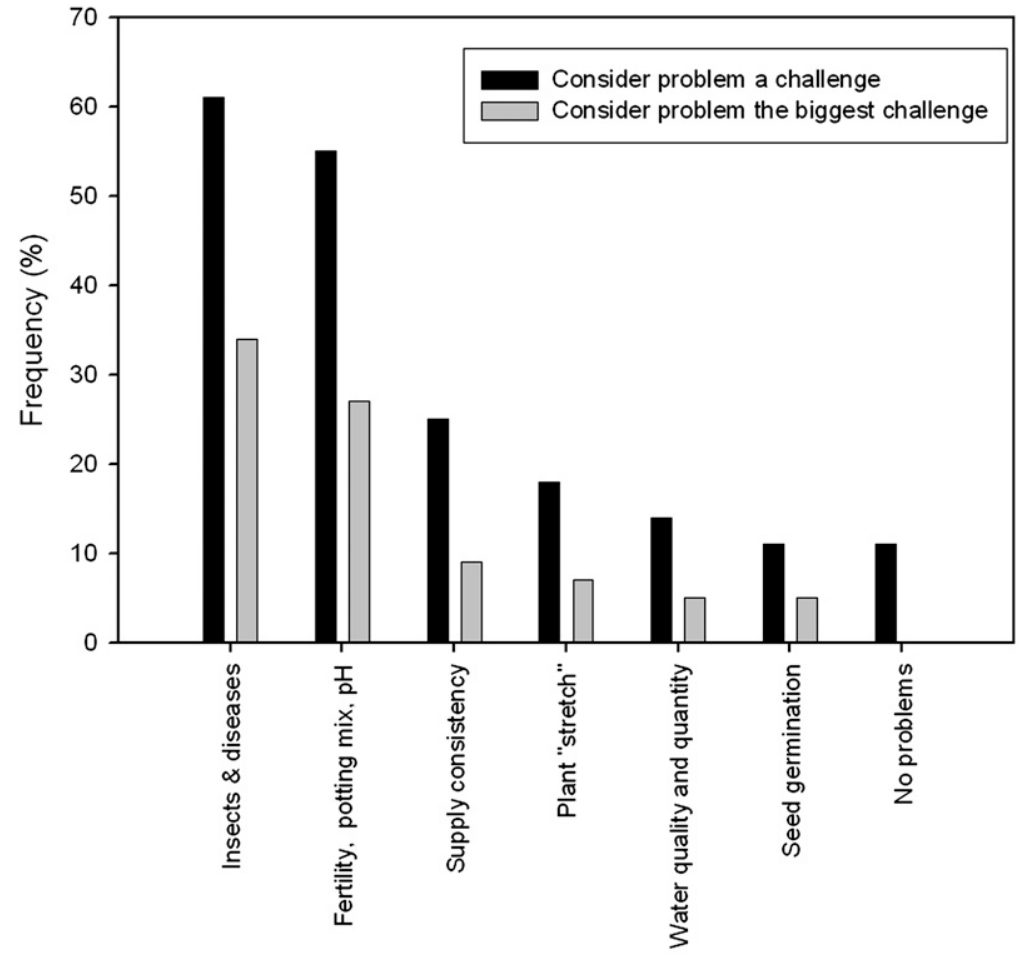

Responses

Fig. 2. Organic growers in Maine were asked to identify which of the following challenges they consider the most difficult in organic production of ornamental bedding plants: Availability or consistency of organic supplies, germinating seeds, managing $\mathrm{pH}$, managing fertility, managing water quality or quantity, managing insect pests, managing diseases, managing plant "stretch," managing the potting mix, or other. They selected any items in the list they considered challenging, thus, the total frequency for all responses is greater than $100 \%$. The following responses: "managing fertility," "managing the potting mix," or "managing $\mathrm{pH}$ " were reported separately, but were combined in the figure. Similarly, responses to "managing insect pests" and "managing diseases" were combined. For the ranking, frequencies represent the number of people who ranked each option as their most difficult challenge (i.e., 1). Responses for "managing fertility" and "managing the potting mix" were combined; responses for "managing insect pests" and "managing diseases" were combined. Percentages only add to $92 \%$ because some respondents did not rank production challenges.

growers reported that they experience no challenges in growing ornamental plants organically. When asked to rank these challenges, no greater than $10 \%$ of growers considered something other than insect and disease management or management of fertility, substrates, and $\mathrm{pH}$ to be their greatest challenge.

SuRvey OF CONVENTIONAL GROWERs. Conventional growers were asked to identify the single greatest barrier to converting to organic ornamental bedding plant production from the following list:

I'm just not interested in organic bedding plant production.

I don't think my customers are interested in buying organic ornamental bedding plants.
Fertilizing a bedding plant crop organically would be too big of a challenge.

Managing insect problems organically would be too big of a challenge.

Managing plant diseases organically would be too big of a challenge.

Other (please specify).

Although we asked growers only to identify the single greatest barrier, $24 \%$ of growers (38 individuals) selected more than one option from the list. For those respondents, we included each of their responses, thus the total frequency is greater than $100 \%$ (Fig. 3).

The largest number of respondents feel that fertility management is the greatest barrier to organic production $[37 \%$ of conventional growers
(Fig. 3)]. Due to the problems described above with organic fertility, it seems logical that fertility management is of concern to conventional and organic growers. Thirty-three percent of conventional growers are concerned about insect management, and $19 \%$ feel that disease management would be too great a challenge in organic production (Fig. 3). Fortyone percent of respondents did not wish to consider organic production due to lack of personal interest or perceived lack of consumer interest (Fig. 3).

Eleven percent of conventional growers wrote in some other barrier that was not provided in the list of options. The most common write-in response was that growers were concerned that the cost of organic production would not be supported by the market. Other growers do not wish to be certified organic because of the cost and/or time involved in becoming certified. In fact, $41 \%$ of growers self-identified as organic have not become certified through the USDA or Maine's local certification board MOFGA. Beginning this year, the USDA plans to reimburse up to $75 \%$ of certification costs to growers in 16 states, including Maine, which could reduce this potential barrier. However, the significant time involved in becoming certified may still be intimidating for some growers. Several other growers reported that they were in the process of converting to organic production or gathering information about organic production.

Nationally, some ornamental bedding plant growers have recently begun to grow a portion of their plants organically. Some growers have also begun to grow organic vegetable and herb transplants for home gardens (Beytes, 2008). This may explain the $83 \%$ increase in certified organic greenhouse and nursery space (USDA, 2006). Thus far, no market research has been conducted to verify consumer interest in organically grown ornamental plants. Before growers transition to organic production, it would be vital to determine whether consumers are interested in purchasing these plants and would pay enough for them to support increased production costs. Furthermore, because little-tono research has been conducted on organic ornamental bedding plant or container plant production, it is vital to 


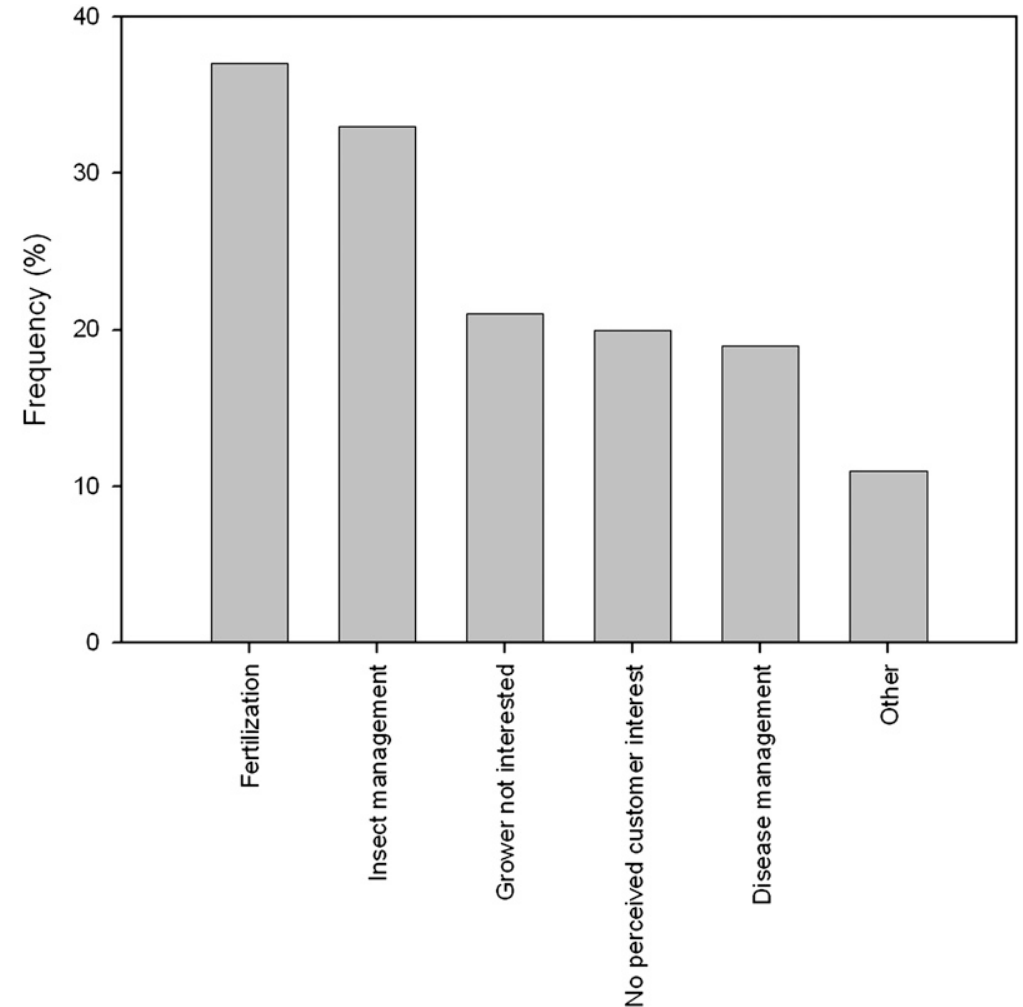

Responses

Fig. 3. Conventional bedding plant growers in Maine were asked to identify their single greatest barrier to transition to organic production from the following list: I'm not interested in organic bedding plant production; I don't think my customers are interested in buying organic ornamental bedding plants; fertilization, managing insect problems, managing plant diseases; or other. Respondents were asked to choose the greatest barrier, however, some growers chose two options. For those responses, each selection was counted, thus, the total frequency is greater than $100 \%$.

identify, prioritize, and research production problems that growers may face if they transition to organic production.

\section{Conclusions}

One new production niche that may be available for conventional bedding plant growers is organic plant production. Organic bedding plant growers in Maine identified insect and disease management as their number one production challenge, and problems with fertility as their second greatest concern. Conventional growers consider fertility management to be the greatest barrier to transitioning to organic production of bedding plants. Future research on organic bedding plant production should focus on fertility management or organic management of insects and diseases.

\section{Literature cited}

Beytes, C. 2008. Business and biology. GrowerTalks 71:46-52.

Bilderback, T.E. 2002. Water management is key in reducing nutrient runoff from container nurseries. HortTechnology 12:541-544.

Brumfield, R.G., A. Rimal, and S. Reiners. 2000. Comparative cost analyses of conventional, integrated crop management, and organic methods. HortTechnology 10:785-793.

Bugbee, G.J. and C.R. Frink. 1989. Composted waste as a peat substitute in peatlite media. HortScience 24:625-627.
Chaney, R.L., J.B. Munns, and H.M. Cathey. 1980. Effectiveness of digested sewage sludge compost in supplying nutrients for soilless potting media. J. Amer. Soc. Hort. Sci. 105:485-492.

Dimitri, C. and C. Greene. 2002. Recent growth patterns in the U.S. Organic Foods Market. U.S. Dept. Agr. Econ. Res. Serv. Agr. Bul. 777.

Durham, C.A. 2007. The impact of environmental and health motivations on the organic share of produce purchases. Agr. Resource Econ. Rev. 36:304-320.

Falahi-Ardakani, A., J.C. Bouwkamp, F.R. Gouin, and R.L. Chaney. 1987. Growth response and mineral uptake of vegetable transplants grown in a composted sewage sludge amended medium. I. Nutrient supplying power of the medium. J. Environ. Hort. 5:107-111.

Jolly, D.A. 1991. Determinants of organic horticultural products consumption based on a sample of California consumers. Acta Hort. 295:141-148.

Kelley, K.M. and J.A. Biernbaum. 2000. Organic nutrient management of greenhouse production of edible flowers in containers. HortScience 35:453. (Abstr.).

Kraus, H.T., R.L. Mikkelsen, and W.L. Warren. 2000. Container substrate temperatures affect mineralization of composts. HortScience 35:16-18.

Kuepper, G. and K. Everett. 2004. Potting mixes for certified organic production. Natl. Sustainable Agr. Info. Serv. Publ. \#IP112. 28 Apr. 2008. <http:// attra.ncat.org/attra-pub/potmix.html>.

Nelson, L., J. Giles, C. Macilwain, and V. Gewin. 2004. Organic FAQs. Nature 428:796-798.

Thompson, G.D. 1998. Consumer demand for organic foods: What we know and what we need to know. Amer. J. Agr. Econ. 80:1113-1118.

U.S. Department of Agriculture. 2006. Data sets: Organic production. 26 Mar. 2007. <http://www.ers.usda.gov/ Data/Organic/>.

Walz, E. 2004. Final results of the fourth national organic farmer's survey: Sustaining organic farms in a changing organic marketplace. Organic Farming Research Foundation, Santa Cruz, CA. 